\title{
A Simple Torsion Pendulum for Measuring Internal Friction
}

\author{
by $M$. E. Fine
}

$I^{\mathrm{N}}$ $\mathrm{N}$ the apparatus for measuring internal friction shown in fig. 1, a modification of that described by $K \hat{e},{ }^{\prime}$ " the parasitic energy loss or background is equivalent to a $Q^{-1}$ of approximately $4 \times 10^{-5}$. This low value of background was obtained by using a jeweler's collet of appropriate size for the upper support, eliminating lateral motion without immersing the bob in oil, and designing the bob to reduce air resistance. The pendulum is supported on the frame through a snug fitting, sliding rotary joint (fig. 1-B). A slight twist of the top imparts essentially pure torsional motion to the pendulum. No evidence of energy loss in the sliding joint has been observed. In the bob $(E)$ steel balls are used in the torsion arm, and the bottom is filled with lead giving a total weight of $94 \mathrm{~g}$. A lighter bob may be used for small diameter specimens. Another bob was a solid disc with provision for adding discs to change the frequency. The oscillating image of the filament is recorded on a revolving drum camera (fig. 1-J) driven by a synchronous motor. This allows use of frequencies higher than can be measured visually on a glass scale.

Samples varying in diameter from 0.020 to 0.075 in. have been measured, the frequencies have ranged from 1 to $12 \mathrm{cps}$, and the maximum strain varied from 0.5 to $10 \times 10^{-\overline{5}}$. With appropriate modification the sample may be placed in a thermostat.

M. E. FINE, Member Technical Staff, Bell Telephone Laboratories, Murray Hill, N. J.

TN 47 E. Manuscript received Aug. 8, 1950.
Table I. Internal Friction of Metal Wires

\begin{tabular}{|c|c|c|c|c|}
\hline Material & Diam & $\begin{array}{l}\text { Freq. } \\
\text { cps. }\end{array}$ & $\begin{array}{l}\text { Max. } \\
\text { Strain }\end{array}$ & $\begin{array}{c}\text { Internal } \\
\text { Friction } \\
\mathbf{Q}^{-1}\end{array}$ \\
\hline \multicolumn{5}{|l|}{ Beryllium-copper } \\
\hline solution treated & 0.058 & 6.4 & $1.2 \times 10^{-5}$ & $6 \times 10^{-5}$ \\
\hline Same, age hardened & 0.058 & 6.6 & 1.2 & 5 \\
\hline Nickel brass, hard drawn & 0.065 & 7.9 & 1.7 & 10 \\
\hline Same, 1.5 mil, lead coating & 0.068 & $\mathbf{8 . 1}$ & 1.2 & 49 \\
\hline \multicolumn{5}{|c|}{ Permendur (50Fe,50Co,0.5Mn) } \\
\hline slowly cooled from $1000^{\circ} \mathrm{C}$ & 0.063 & 10.9 & 3.5 & 350 \\
\hline Same & 0.063 & 10.9 & 1.3 & 99 \\
\hline Same & 0.063 & 1.1 & 3.5 & 290 \\
\hline \multicolumn{5}{|l|}{$\begin{array}{l}\text { Permendur quenched } \\
\text { from } 1000^{\circ} \mathrm{C}\end{array}$} \\
\hline $\begin{array}{l}\text { from } 1000^{\circ} \mathrm{C} \\
82 \mathrm{Mn}, 18 \mathrm{Cu}\end{array}$ & 0.063 & 12.4 & 2.1 & 17 \\
\hline $\begin{array}{l}\text { quenched from } 925^{\circ} \mathrm{C} \text {, } \\
\text { aged } 1 \mathrm{hr} \text { at } 400^{\circ} \mathrm{C}\end{array}$ & 0.061 & 5.1 & 1.0 & 1,750 \\
\hline $\begin{array}{l}\text { 46.8Ni, 0.5Mn,Bal.Fe, } \\
\text { cold worked }\end{array}$ & 0.074 & 11.4 & 1.7 & 20 \\
\hline Same, annealed at $900^{\circ} \mathrm{C}$ & 0.074 & 11.9 & 1.3 & 59 \\
\hline
\end{tabular}

The apparatus may also be used to measure the shear modulus.

In the examples of measurement given in table I the internal friction of Permendur and the 46.8 $\mathrm{Ni}-\mathrm{Fe}$ alloy are due, for the most part, to magnetomechanical hysteresis ${ }^{3}$ (elastic hysteresis accompanying stress-induced magnetostriction) which depends on strain amplitude and increases with annealing. The internal friction of most materials decreases with annealing.

\section{References}

${ }^{1}$ T. S. Kê: Physics Review (1947) 71, 533.

${ }^{2}$ T. S. Kê: Transactions AIME (1948) 176, 448; Metals Technology (June 1948) TP 2370E.

${ }^{3} \mathrm{R}$. Becker and W. Döring: Ferromagnetismus. 365 (1939). J. Springer.

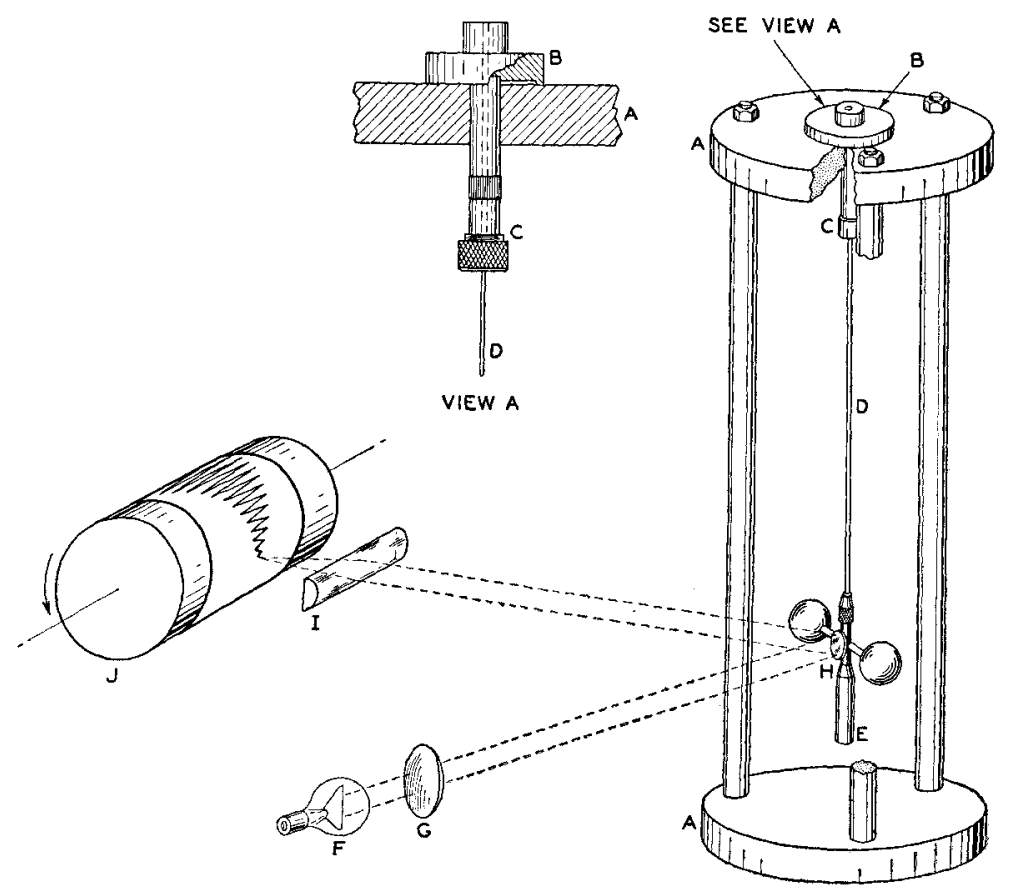

Fig. 1-Torsional pendulum for measuring internal friction.

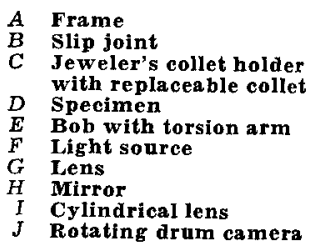

